\title{
Investigations into the Causes and Control of the Growth Arrestment Phenomenon of Sultana. I. Symptoms and Survey Results
}

\author{
D. SAAYMAN \\ Viticultural and Oenological Research Institute, Private Bag X5026, Stellenbosch, 7600, Republic of South Africa. \\ Submitted for publication: July 1982 \\ Accepted for publication: January 1983
}

\begin{abstract}
Growth abnormalities, locally called "growth arrestment phenomenon" (GAP), occurring in the Sultana vineyards in the Lower Orange River region were first described in 1955. Characteristically, single vines or patches of vines are affected, show poor budding, retarded shoot growth during flowering, localised blackening of peduncles and abortion of flower clusters, followed by vigorous renewed shoot growth and flower shatter. Shiny spots on the upper surface of basal leaves are associated with symptoms mentioned above. Because of flower cluster abortion and flower shatter, crop losses exceeding $80 \%$ occurred on affected vines.

An extensive survey and analysis programme revealed GAP to be mainly associated with low $K$ values in soil and plants, a low irrigation frequency, especially during the dormancy period, and relatively heavy textured soils.
\end{abstract}

Vineyards along the banks of the Lower Orange River region in the northern Cape Province comprise more than 8000 ha. and are almost exclusively planted on the dark coloured alluvial soils of the lower river terraces. These soils are fertile and rich in mica-like particles originating from recently weathered schists and granite. Ungrafted Vitis vinifera L. cv. Sultanina vines, trained on T-trellises (Zeeman, 1981) are predominantly planted. More than $50 \%$ of the crop is utilised for raisin production and the balance mainly for distilling wine. The climate of the region corresponds to that of Region V (Winkler et al., 1974) and is characterised by absolute minimum temperatures of less than $0^{\circ} \mathrm{C}$ and absolute maximum temperatures of higher than $28^{\circ} \mathrm{C}$ during the winter months of May to September, reaching values higher than $40^{\circ} \mathrm{C}$ during the growing season. The mean annual rainfall is only $250 \mathrm{~mm}$, of which the largest portion falls during the months of January to March (harvesting period), and the mean daily A-pan evaporation is $11-12 \mathrm{~mm}$ during the peak demand seasons of November to January (Saayman, 1981). Vines are widely spaced (average of $3,2 \times 1,7 \mathrm{~m}$ ), usually clean cultivated and flood irrigated.

The first description of a growth abnormality occurring in the Sultana vines in this region was given by Theron (1955). The symptoms occurred on single vines or in small areas in a vineyard and were thought to be related to poorly developed root systems. The symptoms were described as resembling retarded budding, progressing into the development of stunted new shoots and the abortion of flower clusters, followed by a tendency towards vigorous renewed shoot growth mainly from the trunk. This growth abnormality, resulting in substantial crop losses, was named growth arrestment disease (groeistilstandsiekte), subsequently rechristened as growth arrestment phenomenon (GAP) because no pathological agent could be detected. Apparently it reached such serious proportions in 1955 that Theron (1955) had to persuade producers not to abandon their vineyards because he regarded the dried Sultana product of this region to be of outstanding quality.

Several subsequent investigations followed. De Villiers (1962) suspected that poor root development caused GAP and that climate aggravated it. Pelliesier
(1962) also noted restricted rooting depths but, apart from salinity, did not regard soil as a factor causing GAP.

Although the presence of nematodes, phylloxera, margarodes and mites were established, there was no relationship between their numbers and the occurrence of GAP (Smith, 1971; Rust, 1975). Laker (1967) suspected compacted soil layers, poor potassium $(\mathrm{K})$ nutrition and some trace element deficiencies ( $\mathrm{Zn}, \mathrm{Mn}, \mathrm{B})$ to be involved and, during 1971, initiated the first formal field experiments to test his hypothesis. He eventually reported a low $\mathrm{K}$ content in the soil and leaves to be associated with GAP and found a significant response to deep cultivation during one season, but could not demonstrate this effect in a second experiment, reportedly because of a low K content of the soil (Laker, 1980).

Typical GAP symptoms could be induced with increasing severity by removing increasing portions of the root system of Sultana vines during winter (Smit, 1971). Cuttings from diseased vines planted in pots filled with "diseased" soil and grown under the mediterranean climatic conditions of the Cape, showed abnormal growth only during the first season. It was also observed that certain rootstocks such as 143B MGt. appeared to alleviate GAP, and that GAP was related to heavier textured soil. Again, low K concentrations in the leaves of affected vines and occasionally also in the associated soil, were found to be related to GAP but no response to heavy applications of $\mathrm{K}$ fertiliser was obtained (Smit, 1971). In some cases GAP was also thought to be caused by soil compaction and by $\mathrm{K}$ deficiencies, also supposedly the cause of red death (rooidood) of cotton, as described by Van der Merwe $(1969,1970)$.

The 1966 season was characterised by severe GAP, and a co-ordinated investigation, headed by the VORI, was initiated. An aerial survey, using multispecial techniques was initially done in an effort to identify and quantify affected vines and vineyards. GAP affected vines could readily be identified by this technique because of a smaller volume of new shoot growth (Burger, 1972). Although it was hoped that possible soil variation or latent GAP could be identified by this method, variation in ground cover made this impossible. This approach was consequently abandoned. 


\section{MATERIALS AND METHODS}

As an initial screening process, an extensive survey, comprising more than $30 \%$ of a total of 900 producers, was launched during which all factors possibly related to GAP were investigated. The selected vineyards were randomly chosen and classified as (a) presently affected, (b) having a GAP history but currently healthy and (c) healthy according to producers' evidence and actual investigations.

Because all abnormalities were usually ascribed to GAP, a symptom index was evolved and tested for its validity in describing GAP. This index was based on the absence of (1) developed buds and (2) new leaves, (3) the mean length of new shoot growth (in a negative sense), the occurrence of (4) grey inflorescence and (5) black peduncles, (6) the degree of flower shatter and (7) the presence of shiny spots on basal leaves. Each symptom was scored out of a maximum of 3 points, resulting in a 7-21 scale with high values indicating severe GAP.

In addition to the aerial survey (Burger, 1972), production, viticultural and cultivation data were collected for all selected vineyards by means of questionnaires, measurements of yield and shoot growth made for three consecutive years in 8-vine plots in all selected vineyards, soil samples taken from profile pits which were made in each plot, as well as samples of bearer canes and new shoot growth from each plot during the GAP phase (October, flowering stage). All samples were analysed for the usual macro- and micro elements, and mechanical analyses were done on soil samples, using standard VORI procedures.

\section{RESULTS AND DISCUSSION}

GAP Symptoms: GAP is firstly manifested by poor bud burst, resembling retarded budding of fruit trees, the sparsely budded long canes being clearly visible on affected vines, locally called white shoot (witloot; Plate 1). Buds which do develop tend to stop growing during flowering stage, leading to the name of GAP. The young shoots acquire a stunted appearance; have short internodes; small, dark and sometimes deformed green leaves, giving the affected vine a clearly dark green appearance; no active growing tips and proportionally large flower clusters with a smaller volume of new growth compared to normal vines (Plate 2).

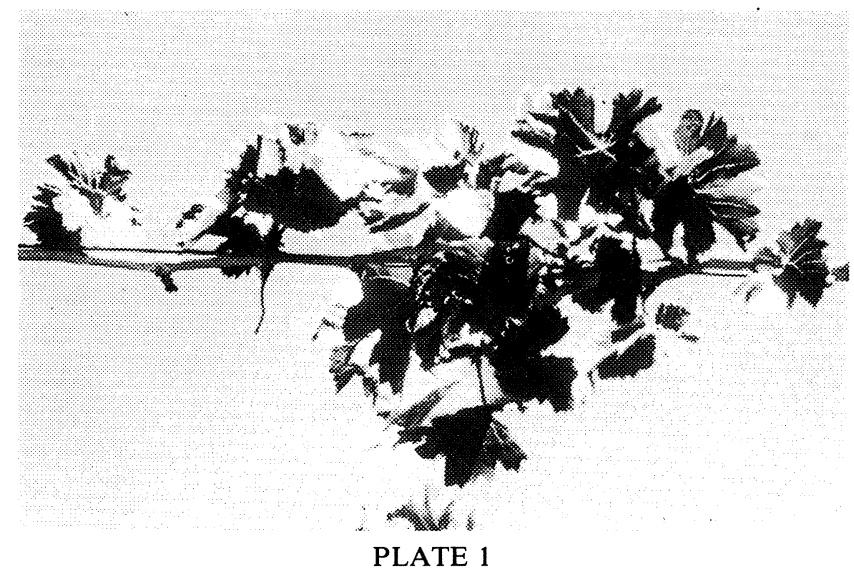

White shoot symptom. Canes show poor and uneven budding, with the new shoots having no actively growing tips, a stunted and dark green appearance.

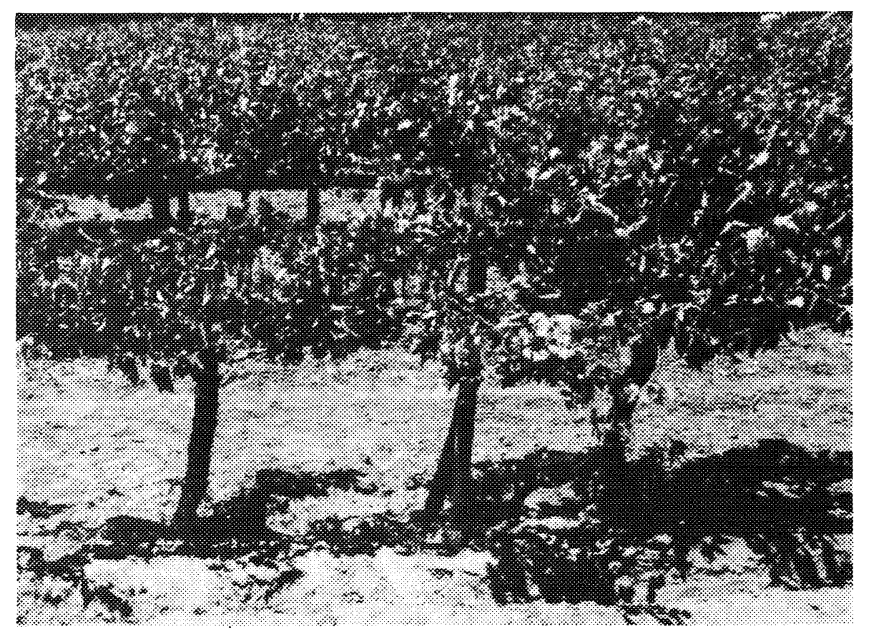

PLATE 2

A GAP afflicted vine (left), showing a small volume of new growth in comparison with adjacent normal appearing vine (compare shadows), which is lighter green in colour due to actively growing shoot tips.

At this stage the flower clusters may develop dark coloured necrotic zones or girdles around the peduncles and/or pedicles, the so-called black bunch (swarttros) symptom (Plate 3 ), frequently resulting in the complete abortion of the flower cluster, but occasionally recovering from the lesions (Plate 4). In severe cases the

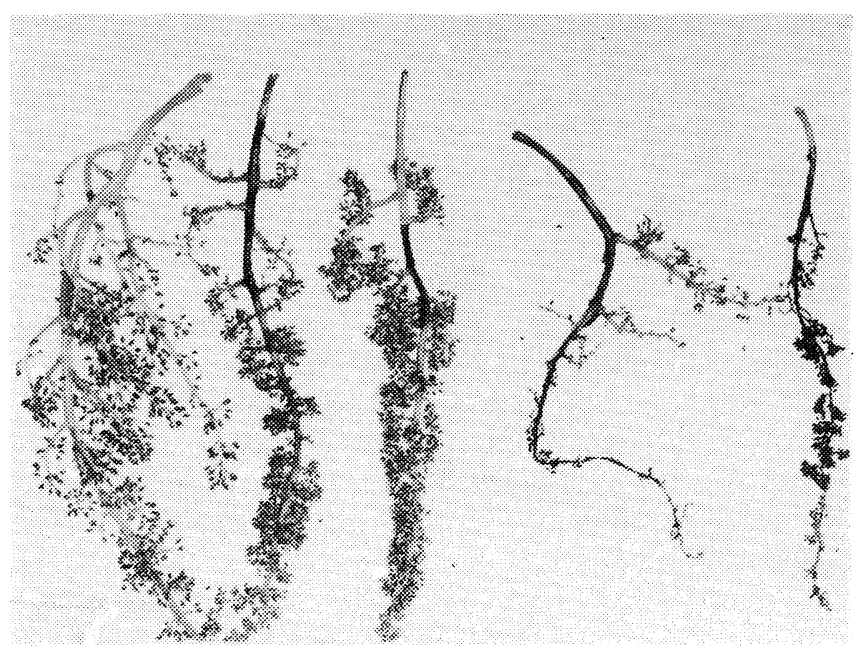

PLATE 3

Flower clusters showing darkening of peduncles in varying degrees of severity (After Terblanche, 1974; photo FFTRI).

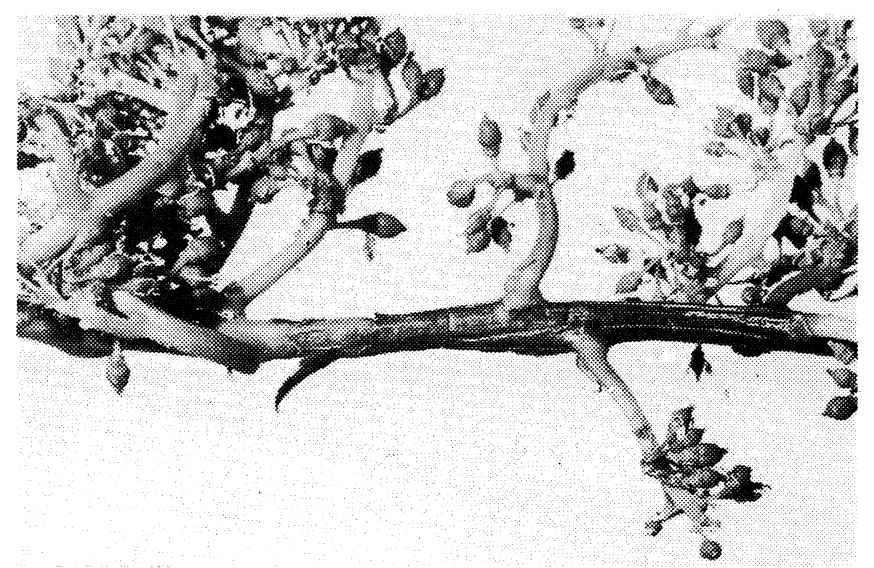

PLATE 4

Signs of peduncle recovering from "black bunch" lesions (After Terblanche, 1974; photo FFTRI). 
growing tip of the stunted new shoot dies, and the inflorescence dries up at a very early stage of development (Plate 5), resulting in the so-called grey bunch (vaaltrossie) symptom.

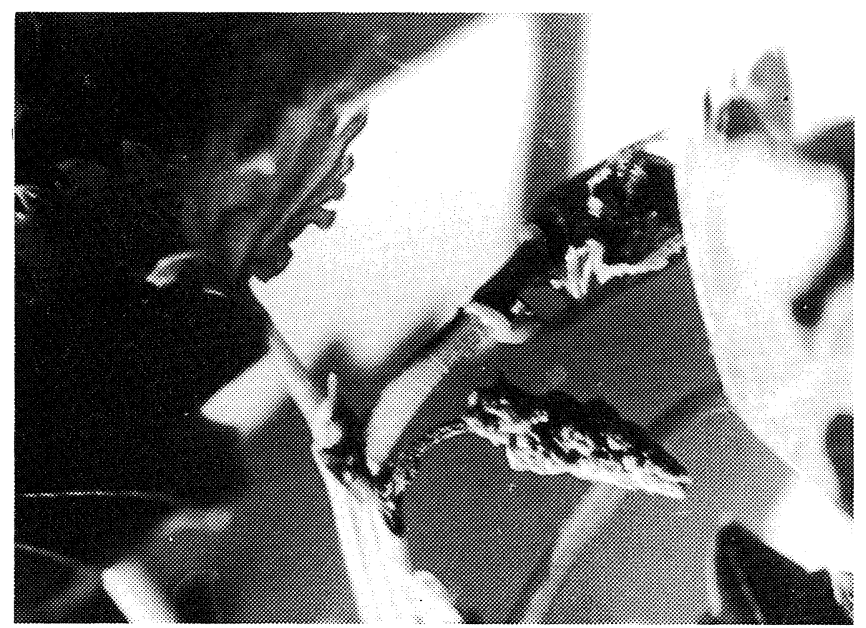

PLATE 5

"Grey bunch" symptom. Dried growing tip and inflorescence, with new lateral shoot (upper, right).

During and after flowering vigorous shoot growth recommences, notably from the crown of the vine, eventually resulting in an even larger volume of new growth than that of normal vines. GAP prone vines are encountered singly or in patches, are clearly distinguishable from above (Plate 6) and usually have thicker trunks than neighbouring healthy vines.

Several grades of GAP seem to exist because seemingly normal growing shoots may show black bunch and/or severe flower shatter symptoms, resulting in severe crop losses. The flower shatter phenomenon of normal looking clusters appears to be related to vigorous shoot growth or to shoots that had just recovered from the retarded growth phase (Terblanche, 1974). Another symptom associated with GAP is the socalled shiny spot (blinkvlek) leaf phenomenon, deriving its name from shiny spots occurring on the upper surface of basal leaves (Plate 7). These spots are formed by collapsed epidermis cells (De la Harpe \& Archer, 1981) and vary in size from spots as large as pin heads to large areas which tend to be contained between secondary and main veins.

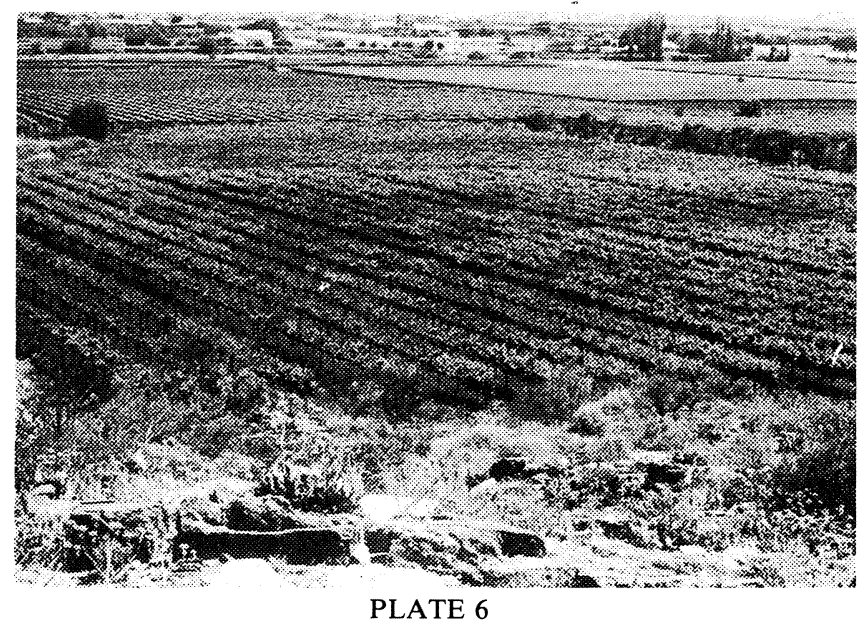

Dark coloured patches in the Sultana vineyard in the foreground indicating the presence of GAP.

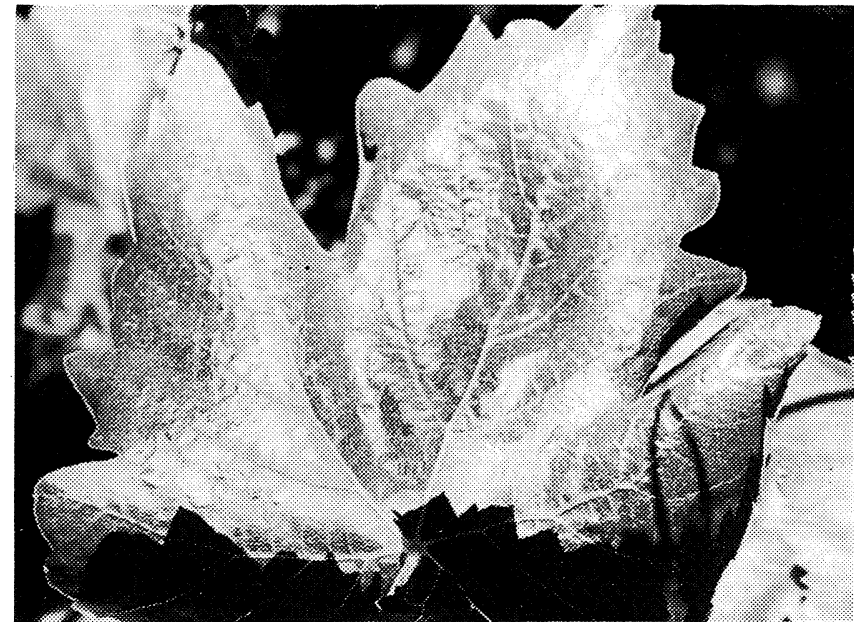

PLATE 7

Shiny spots symptom on the upper surface of basal leaves.

Correlating the GAP symptom indices for each of the c. 300 selected plots to yield, a highly significant relationship between GAP symptoms and crop loss could be demonstrated, indicating that these symptoms were true GAP symptoms.

Although not always associated with GAP, still another symptom, namely curled leaf (krulblaar), is commonly encountered and seems to be related to vigorous growth. This symptom is characterised by an upward and inward curling of older leaves which have a thin appearance and are dark green in colour (Plate 8). This phenomenon is apparently not caused by moisture stress because young shoot tips show no signs of wilting (Plate 9).

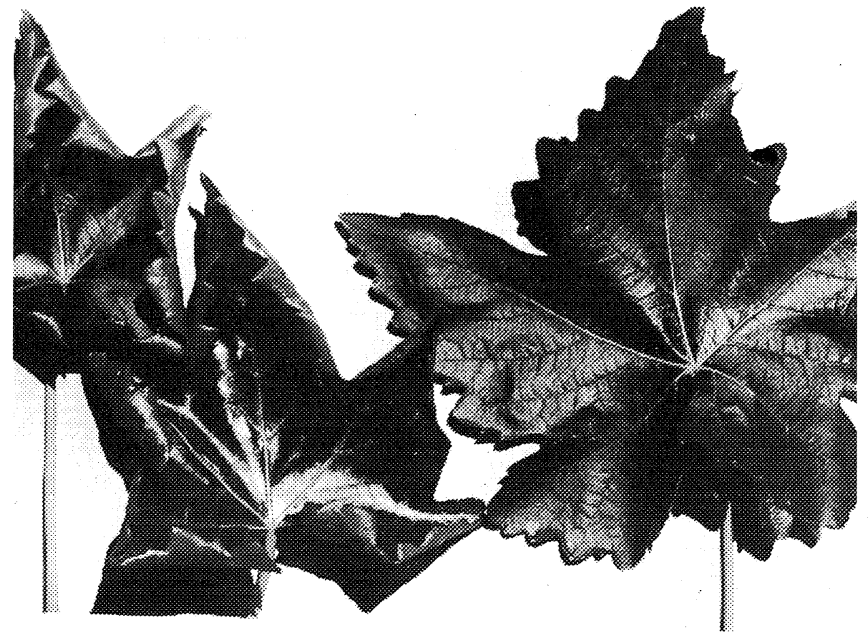

PLATE 8

Curled leaf symptom of Sultana, usually associated with vigorous growth. Normal leaf on the right.

GAP also appears to be affected by climatic conditions because the severity of GAP fluctuates considerably according to the season. Smit (1971) reported 1955, 1956, 1960 and 1966 as severe GAP seasons according to production statistics and found indications of a relationship between high temperatures during winter dormancy and the incidence of GAP. By keeping soil 


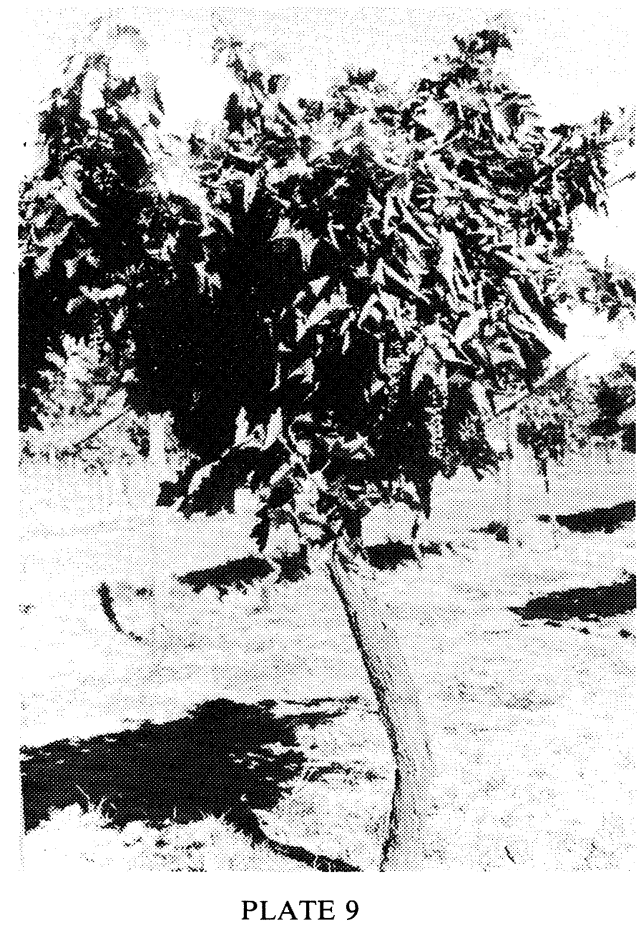

Sultana vine showing severe curled leaf symptoms, resembling moisture stress, but with the young shoot tips unaffected.

temperatures at $10-14^{\circ} \mathrm{C}$ and the ambient temperatures at c. $25^{\circ} \mathrm{C}$, interspersed with peaks of higher than $30^{\circ} \mathrm{C}$, thus simulating actual temperature conditions experienced in the Lower Orange River region, interesting growth abnormalities could be produced at Stellenbosch on mature Sultana vines grown in GAP soil in large containers. Budding was uneven and inflorescences aborted at a very early stage, resembling "white shoot" and "grey bunch" symptoms. Some leaves showed deformities resembling bud mite damage, and tendrils tended to develop into flower clusters and even sprouted a leaf in one case (J. H. van der Westhuizen, 1981 - personal communication; Plate 10).

Survey Results: In Table 1 data obtained during the general survey and chemical analyses program are shown. The severe effect of GAP on production is evident, causing a crop loss of more than $80 \%$ without affecting shoot mass. The frequency and quantity of irrigation water supplied, especially during the dormancy period, were shown to differ markedly between GAP and normal plots. The soils of GAP vines had a lower $\mathrm{K}$ content and higher $\mathrm{Na}, \mathrm{Mg}, \mathrm{Ca}$ and $\mathrm{B}$ content and was also heavier in texture than soils of normal vines. The chemical properties of the soil are partly reflected by the nutrient content of one year old canes at flowering time (Table 2). Formerly unknown or ignored factors were the distinctly higher $\mathrm{N}, \mathrm{Mn}$ and $\mathrm{Zn}$ contents of canes. This could hardly be attributed to a concentration effect because the shoot mass of GAP and normal vines were of the same order. However, concerning the nutrient content of new growth, all the elements except $\mathrm{K}$ were present in highly significant higher concentrations in GAP than in normal plant material, indicating a possible concentration effect due to the smaller growth at this stage.

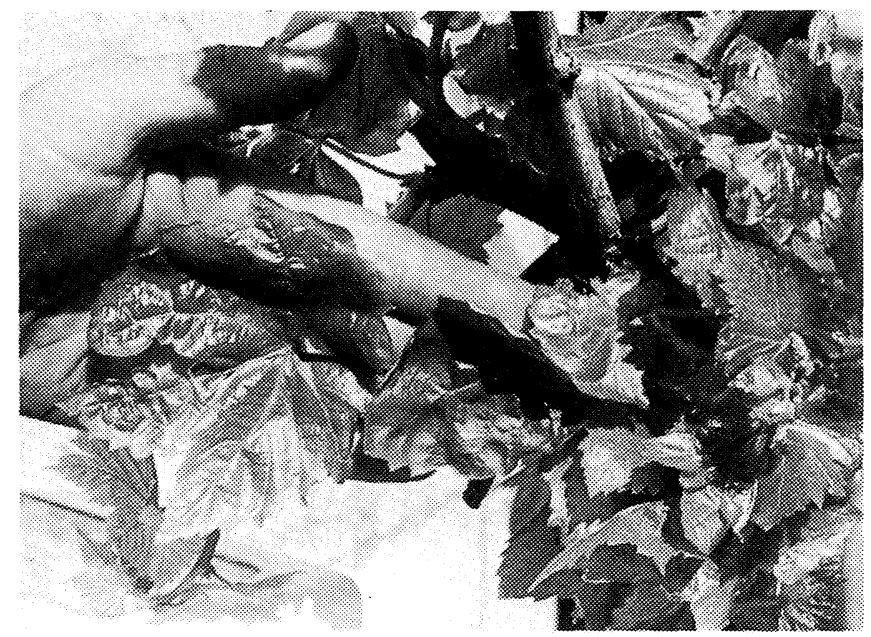

(a)

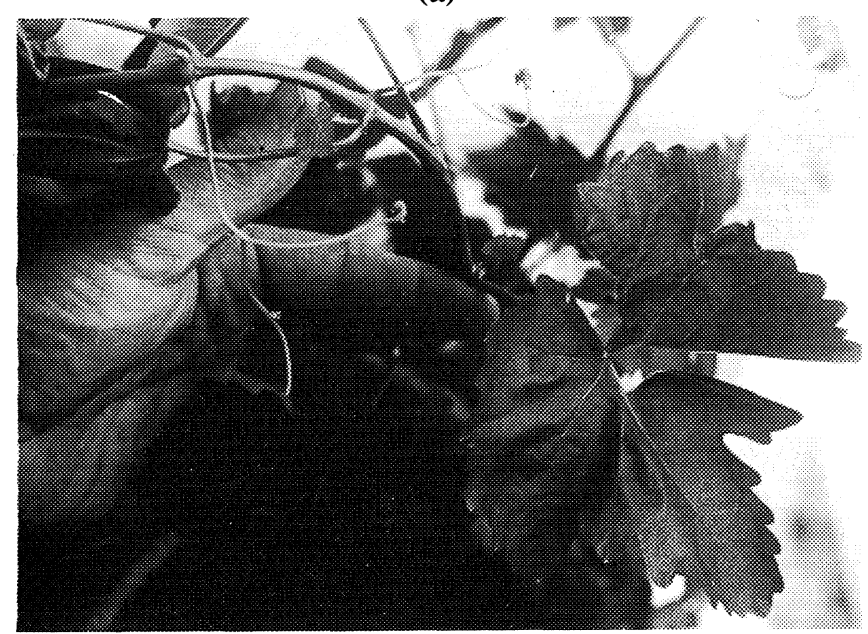

(b)

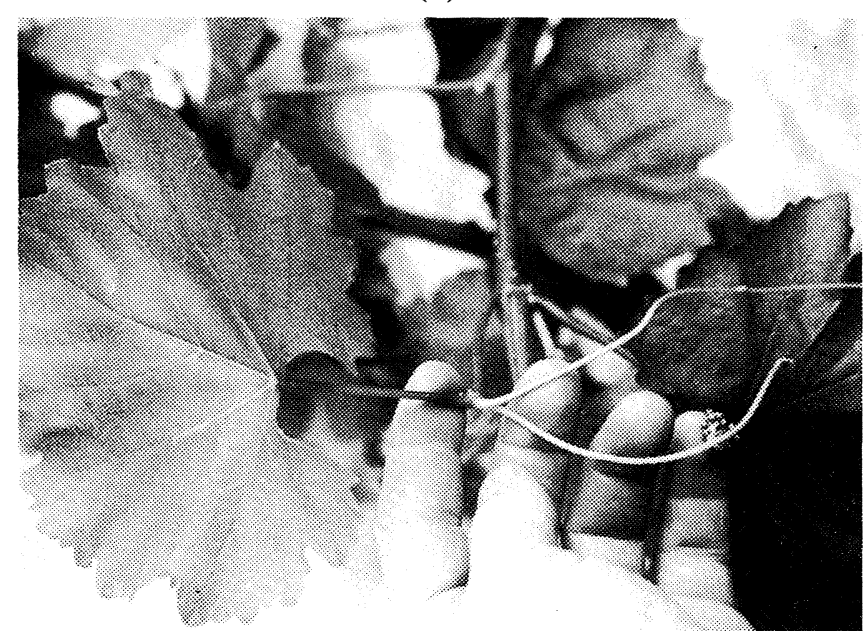

(c)

PLATE 10

Abnormal growth symptoms caused by contrasting soil and ambient temperatures. Deformities in (a) young and (b) older Sultana leaves with (c) a tendril sprouting a leaf and showing tendencies to develop into a cluster. (Photos: J. H. van der Westhuizen).

\section{CONCLUSIONS}

The symptoms most consistently associated with GAP appear to be retarded and poor budding, arrestment of shoot growth during flowering, blackening of peduncles 
TABLE 1

Vine performance, cultural practices and soil properties associated with GAP and normal Sultana vines, Lower Orange River region.

\begin{tabular}{|c|c|c|c|c|c|c|}
\hline Property Measured & \multicolumn{2}{|c|}{ Normal vines } & \multicolumn{2}{|c|}{ GAP vines } & \multicolumn{2}{|c|}{ Significance 1) } \\
\hline GAP index $\left.{ }^{2}\right)$ & \multicolumn{2}{|c|}{8,7} & \multicolumn{2}{|c|}{15,9} & \multicolumn{2}{|c|}{$* *$} \\
\hline Crop mass (t/ha) & \multicolumn{2}{|c|}{35,0} & \multicolumn{2}{|c|}{5,5} & \multicolumn{2}{|c|}{$* *$} \\
\hline Shoot mass (kg/vine) & \multicolumn{2}{|c|}{1,32} & \multicolumn{2}{|c|}{1,30} & \multicolumn{2}{|c|}{ ns } \\
\hline \multicolumn{7}{|l|}{ Number of irrigations: } \\
\hline Dormancy (May-Sept.) & \multicolumn{2}{|c|}{2,1} & \multicolumn{2}{|c|}{0,8} & \multicolumn{2}{|c|}{ * } \\
\hline Growing period (Sept.-April) & \multicolumn{2}{|c|}{10,5} & \multicolumn{2}{|c|}{8,4} & \multicolumn{2}{|c|}{$*$} \\
\hline \multicolumn{7}{|l|}{ Quantity of irrigation water $(\mathrm{mm})$ : } \\
\hline Dormancy & \multicolumn{2}{|c|}{148} & \multicolumn{2}{|c|}{68} & \multicolumn{2}{|c|}{$* *$} \\
\hline Growing period & \multicolumn{2}{|c|}{748} & \multicolumn{2}{|c|}{651} & \multicolumn{2}{|c|}{$*$} \\
\hline Soil properties: & Topsoil 3) & Subsoil 3 ) & Topsoil 3) & Subsoil ${ }^{3)}$ & Topsoiß ${ }^{3)}$ & Subsoil 3) \\
\hline $\mathrm{pH}(\mathrm{KC} 1)$ & 6,66 & 6,53 & 6,63 & 6,50 & ns & ns \\
\hline Electrical resistance (ohm) & 503 & 833 & 503 & 876 & ns & ns \\
\hline Exchangeable $\mathrm{K}(\mathrm{me} \%)$ & 0,61 & 0,21 & 0,52 & 0,25 & * & $*$ \\
\hline Exchangeable $\mathrm{Na}\left(\mathrm{me}^{\circ}\right)$ & 0,26 & 0,32 & 0,36 & 0,42 & $*$ & $* *$ \\
\hline Exchangeable $\mathrm{Mg}\left(\mathrm{me}^{\%}\right)$ & 4,8 & 4,1 & 5,2 & 4,3 & ns & ns \\
\hline Olsen P (ppm) & 11,0 & 3,1 & 11,0 & 2,4 & ns & ns \\
\hline EDTA-Zn (ppm) & 1,30 & 0,95 & 1,22 & 0,75 & ns & $*$ \\
\hline Warm water - B (ppm) & 0,23 & 0,13 & 0,34 & 0,22 & $* *$ & $* *$ \\
\hline Clay $(\%)$ & 10,3 & 5,1 & 11,6 & 5,7 & $*$ & $*$ \\
\hline Silt $(\%)$ & 11,8 & 8,3 & 13,4 & 8,7 & $*$ & $*$ \\
\hline Fine sand $(\%)$ & 71,3 & 78,6 & 71,0 & 77,4 & ns & ns \\
\hline Medium and coarse sand $(\%)$ & 6,6 & 8,0 & 4,0 & 8,2 & ns & ns \\
\hline
\end{tabular}

1) **Highly significant $(\mathrm{P} \leq 0,01) ; \quad *$ Significant $(\mathrm{P} \leq 0,05) ; \mathrm{ns}=$ not significant

2) Index was based on the presence of defined symptoms, resulting in a 7-21 scale with high values indicating severe GAP

3) Topsoil depth, 0-30 cm; subsoil depth $30-60 \mathrm{~cm}$.

TABLE 2

Nutrient content of canes and new growth of normal and GAP afflicted Sultana vines at flowering stage, October 1972, Lower Orange River region

\begin{tabular}{|c|c|c|c|c|}
\hline $\begin{array}{l}\text { Organ } \\
\text { Sampled }\end{array}$ & Element & $\begin{array}{l}\text { Normal } \\
\text { vines }\end{array}$ & $\begin{array}{l}\text { GAP } \\
\text { vines }\end{array}$ & $\begin{array}{l}\text { Signi- } \\
\text { ficance }^{1)}\end{array}$ \\
\hline \multirow{9}{*}{$\begin{array}{l}\text { Bearer } \\
\text { canes }\end{array}$} & $\mathrm{N}(\%)$ & 0,48 & 0,62 & $* *$ \\
\hline & $P(\%)$ & 0,12 & 0,14 & ns \\
\hline & $\mathrm{K}(\%)$ & 0,66 & 0,52 & $* *$ \\
\hline & $\mathrm{Na}(\%)$ & 0,02 & 0,05 & $* *$ \\
\hline & $\mathrm{Ca}(\%)$ & 0,59 & 0,58 & ns \\
\hline & $\operatorname{Mg}(\%)$ & 0,11 & 0,13 & $* *$ \\
\hline & $\mathrm{Fe}(\mathrm{ppm})$ & 74 & 82 & ns \\
\hline & $\mathrm{Mn}(\mathrm{ppm})$ & 19 & 24 & $* *$ \\
\hline & $\mathrm{Zn}(\mathrm{ppm})$ & 42 & 61 & $* *$ \\
\hline \multirow{9}{*}{ New growth } & $N(\%)^{2)}$ & - & - & - \\
\hline & $P(\%)$ & 0,81 & 0,89 & $* *$ \\
\hline & $\mathrm{K}(\%)$ & 1,33 & 1,07 & $* *$ \\
\hline & $\mathrm{Na}(\%)$ & 0,05 & 0,07 & $* *$ \\
\hline & $\mathrm{Ca}(\%)$ & 1,37 & 1,54 & $* *$ \\
\hline & $\operatorname{Mg}(\%)$ & 0,27 & 0,35 & $* *$ \\
\hline & $\mathrm{Fe}(\mathrm{ppm})$ & 115 & 137 & $* *$ \\
\hline & $\mathrm{Mn}(\mathrm{ppm})$ & 78 & 100 & $* *$ \\
\hline & $\mathrm{Zn}(\mathrm{ppm})$ & 29 & 49 & $* *$ \\
\hline
\end{tabular}

1) **Highly significant $(\mathrm{P} \leq 0,01)$; Significant $(\mathrm{P} \leq 0,05)$; ns $=$ Not significant

2) $\mathrm{N}$ was not determined on new growth material.

and/or abortion of flower clusters, followed by renewed vigorous shoot growth and flower shatter, while basal leaves show shiny spot symptoms. Curled leaf symptoms seem to be associated with vigorous growth but not necessarily with GAP.

The indications obtained by means of the preliminary survey and analytical work point to poor $\mathrm{K}$ nutrition of the new growth and inadequate irrigation practices as possible contributing factors to GAP, with the high $\mathrm{Na}$ contents in the soil and heavier soil textures associated with GAP vines also contributing.

The phenomenon that GAP vines may have a very low yield in one year, followed by a yield even higher than that of normal vines the following year, points to overcropping as another possible contributing factor. Furthermore, the inconsistency of GAP affliction from one season to the other points to climate as another complicating factor. Because of sparse budding and retarded growth, it is postulated that either reserves were not efficiently hydrolised in spring, or that there is an absolute deficiency of reserves which cause poor budding, arrested growth and flower abortion or shatter.

\section{LITERATURE CITED}

BURGER, J. D., 1972. The use of remote sensing in the identification of Growth Arrestment Disease. Proc. of the Symposium on remote sensing, 3-5 May, CSIR, Pretoria 0001, Dept. Agric. Tech. Services, 107-110.

DE LA HARPE, A.C. \& ARCHER, E., 1981. Effect of Growth Arrestment Disease on the anatomy and ultrastructure of Vitis vinifera L. var. Sultana. S. Afr. J. Enol. Vitic. 2(2), 51-59.

DE VILLIERS, G. D. B., 1962. 'n Ondersoek na die groeiverskynsel by Sultanastokke, bekend as Groeistilstandsiekte te Upington, Louisvale en Keimoes op 15 en 16 Oktober 1975. Unpublished report, Dept. Meteorology, Univ. OFS, Bloemfontein, 9300.

LAKER, M. C., 1967. Enkele gedagtes oor "Groeistilstandsiekte", Unpublished report, Faculty of Agriculture, Univ. OFS, Bloemfontein, 9300 .

LAKER, M. C., 1980. Voorlopige ondersoeke na die moontlike verband tussen grondfaktore en die voorkoms van Groeistilstandsiekte van Sultanas langs die Benede-Oranjerivier. Grondkundevereniging van Suidelike Afrika. Handelinge, Negende Nasionale Kongres, Jan. 1980, Durban, 44-49. Technical Communication No 174, Dept. Agric. Tech. Services, Pretoria 0001. 
PELLIESIER, M., 1962. Besoek aan Upington in sake Groeistilstandsiekte op 15 en 16 Oktober 1962. Unpublished report, Dept. Agric. Tech. Services, Glen, 9360, OFS.

RUST, D. J., 1975. Verslag: Die verband tussen myte en Groeistilstandsiekte by wingerd. Upington 15 tot 17 Oktober 1975 Unpublished report, FFTRI, Stellenbosch, 7600.

SAAYMAN, D., 1981. Grond, koimaat en wingerdbougebiede. In: Wingerdbou in Suid-Afrika, 48-66. Eds. J. D. Burger \& J. Deist. VORI, Stellenbosch, 7600.

SMIT, C. J., 1971. Verskillende bevindings insake Groeistilstandsiekte. Unpublished report, VORI, Stellenbosch, 7600.

SMITH, P. C., 1971. Moontlike verband tussen grondplae en Groeistilstandsiekte langs die Benede-Oranjerivier. Samevatting van gegewens beskikbaar tot op datum (Junie 1971) en wenke vir verdere navorsing. Unpublished report, RIPP, Stellenbosch, 7600 .
TERBLANCHE, J. H., 1974. Besoek aan Upington gebied in verband met Groeistilstandsiekte (24 -26/10/73). Unpublished report, FFTRI,' Stellenbosch, 7600.

THERON, C. J., 1955. Oranjerivier-Wingerde. Unpublished report, Faculty of Agriculture, Univ. Stellenbosch, Stellenbosch, 7600.

VAN DER MERWE, A. J., 1969. Chemiese ondersoek van die Rooidoodprobleem by katoen in die westelike besproeiingsgebiede. Agrochemophysica 1, 87-92.

VAN DER MERWE, A. J., 1970, 'n Samevatting van gegewens insake Rooidood. Unpublished report, Dept. Agric. Tech. Services, Glen 9360, OFS.

WINKLER, A. J., COOK, J. A., KLIEWER, W. M. \& LIDER, L. A., 1974. General Viticulture. Univ. Calif. Press, Berkeley.

ZEEMAN, A. S., 1981. Oplei. In: Wingerdbou in Suid-Afrika, 185-201. Eds. J. D. Burger \& J. Deist. V.O.R.I., Stellenbosch, 7600 . 